research

\title{
Increased glucocorticoid activation during mouse skin wound healing
}

\section{Ana Tiganescu, Melanie Hupe, Yoshikazu Uchida, Theodora Mauro, Peter M Elias and Walter M Holleran}

Department of Dermatology, University of California San Francisco, 1700 Owens Street, San Francisco, California 94158, USA
Correspondence should be addressed to A Tiganescu Email ana.tiganescu@ncire.org

\begin{abstract}
Glucocorticoid (GC) excess inhibits wound healing causing increased patient discomfort

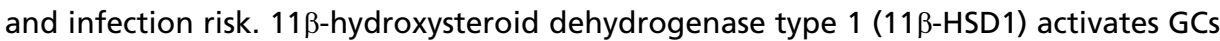
(converting 11-dehydrocorticosterone to corticosterone in rodents) in many tissues including skin, where de novo steroidogenesis from cholesterol has also been reported. To examine the regulation of $11 \beta-H S D 1$ and steroidogenic enzyme expression during wound healing, $5 \mathrm{~mm}$ wounds were generated in female SKH1 mice and compared at days $0,2,4,8,14$, and 21 relative to unwounded skin. 11ß-HSD1 expression (mRNA and protein) and enzyme activity were elevated at 2 and 4 days post-wounding, with $11 \beta$-HSD 1 localizing to infiltrating inflammatory cells. $11 \beta-H S D 2$ (GC-deactivating) mRNA expression and activity were undetectable. Although several steroidogenic enzymes displayed variable expression during healing, expression of the final enzyme required for the conversion of 11-deoxycorticosterone to corticosterone, 11 $\beta$-hydroxylase (CYP11B1), was lacking in unwounded skin and post-wounding. Consequently, 11-deoxycorticosterone was the principal progesterone metabolite in mouse skin before and after wounding. Our findings demonstrate that $11 \beta$-HSD1 activates considerably more corticosterone than is generated de novo from progesterone in mouse skin and drives GC exposure during healing, demonstrating the basis for $11 \beta-$ HSD 1 inhibitors to accelerate wound repair.
\end{abstract}
Key Words
- 11ß-hydroxysteroid dehydrogenase
- steroidogenesis
- glucocorticoid
skin
wound healing

Journal of Endocrinology (2014) 221, 51-61

\section{Introduction}

Glucocorticoid (GC) excess, whether of endogenous (e.g., Cushing's syndrome, stress) or exogenous (e.g., topical or systemic therapy) origin, adversely affects multiple elements of wound healing, causing prolonged discomfort and increased infection risk. Mechanisms include interference with epidermal growth factor signaling, epidermal cell migration and re-epithelialization (Lee et al. 2005), keratinocyte growth factor signaling and cross-talk between dermal fibroblasts and epidermal keratinocytes (Brauchle et al. 1995, Chedid et al. 1996), transforming growth factor- $\beta$ signaling (Frank et al. 1996), and the IGF1 system (Bitar 2000), although the complex associations between these inter-related pathways are not fully understood.

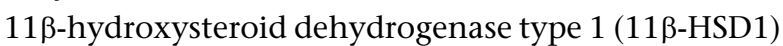
is a bidirectional enzyme that, in intact cells, generates corticosterone from 11-dehydrocorticosterone (11-DHC) in rodents (and cortisol from cortisone in humans), regulating local GC availability. In contrast, 11ß-hydroxysteroid dehydrogenase type 2 (11ß-HSD2) mediates the opposing conversions and is expressed predominantly in mineralocorticoid-responsive tissues (e.g., kidney),

Published by Bioscientifica Ltd. 
preventing inappropriate activation of the mineralocorticoid receptor by GC (Quinkler \& Stewart 2003). In placenta, $11 \beta$-HSD2 also protects the developing embryo from excessive exposure to maternal circulating GC (Brown et al. 1996). 11ß-HSD1 is ubiquitously expressed with well-defined physiological and pathological roles in the liver, brain, muscle, bone, and adipose tissue (Tomlinson et al. 2004, Cooper \& Stewart 2009). Recently, $11 \beta$-HSD expression and activity were also characterized in human and rodent skin (Tiganescu et al. 2011), a tissue in which GC metabolism remains relatively unexplored.

Previous studies have also established a role for extraadrenal GC generation from cholesterol in skin (reviewed by Slominski et al. 2012). Expression of steroidogenic enzymes in this pathway, including cytochromes CYP11A1, CYP17A1, and CYP21A2 has been detected in human skin (Slominski et al. 1996), with cortisol synthesis detected in hair follicles (Ito et al. 2005), keratinocytes (Cirillo \& Prime 2011, Hannen et al. 2011, Vukelic et al. 2011), melanocytes (Slominski et al. 2005a), and fibroblasts (Slominski et al. 2005b, 2006). Corticosterone synthesis has also been detected in rodent skin (Slominski et al. 2000a).

Interestingly, early studies demonstrated GC metabolism during wound healing (Nabors \& Berliner 1969) two decades before the purification and cloning of $11 \beta$ HSD (Lakshmi \& Monder 1988, Agarwal et al. 1989). However, although a recent study has identified a possible role for de novo GC synthesis during wound repair (Vukelic et al. 2011), the regulation of $11 \beta$-HSDs during wound healing remains unexplored.

In this report, we examined $11 \beta$-HSD and steroidogenic enzyme expression and activity during mouse skin wound healing. Although corticosterone synthesis from progesterone was detectable at low levels, 11ß-HSD1mediated corticosterone generation was significantly greater. Furthermore, 11 $\beta$-HSD1 levels increased during wound healing supporting the results of previous studies by us and others, demonstrating accelerated wound healing following local or global 11ß-HSD1 blockade (Terao et al. 2011, Tiganescu et al. 2013). Our findings indicate that increased 11ß-HSD1 activity originates from the infiltrating leukocytes during the inflammatory stage of wound healing. Therefore, 11ß-HSD1 may also contribute to the pathology of chronic wounds characterized by persistent inflammation. Collectively, these findings demonstrate that elevated 11ß-HSD1 may limit wound repair and support the use of local $11 \beta$-HSD1 blockade to promote wound healing.

\section{Materials and methods}

\section{Declarations}

Studies presented in this paper were approved by the Institutional Animal Care and Use Committee and San Francisco Veterans Affairs Medical Center Veterinary Medical Unit. Materials were obtained from Sigma-Aldrich unless otherwise stated.

\section{Wounding studies}

Female SKH1 hairless mice (8-10 weeks) were obtained from Charles River Labs (Wilmington, MA, USA) and acclimatized in-house for 2 weeks before initiation of experiments. Females were chosen due to their lower aggressiveness, which may have increased wound healing rate variability. Mice were group-housed (four per cage), supplied with a basal chow diet and allowed to feed ad libitum, and exposed to a standard $12 \mathrm{~h}$ light: $12 \mathrm{~h}$ darkness cycle.

Mice were anesthetized under 2\% isoflurane. Mid-line upper dorsal skin (a site with minimal risk for secondary trauma from scratching/grooming) was lifted from underlying fascia and wounded using a $5 \mathrm{~mm}$ biopsy punch (Acuderm, Fort Lauderdale, FL, USA) resulting in two symmetrical biopsies on the upper right and left flanks. Wounds received $20 \mu \mathrm{l}$ bupivacaine $0.25 \%$ (analgesic) before recovery and were monitored daily throughout the experimental period.

At $2,4,8,14$, and 21 days post-wounding, mice were killed and wounds were photographed before excision by $5 \mathrm{~mm}$ punch biopsy. Unwounded skin was obtained from the lower dorsal region to control for systemic effects. Adrenal glands were harvested as positive controls for steroidogenic enzyme expression and activity assays. Wound areas were determined using ImageJ (NIH, Bethesda, MD, USA).

\section{Quantitative PCR}

Freshly isolated tissue (20-40 mg skin or whole adrenal) was immediately snap-frozen and stored at $-80^{\circ} \mathrm{C}$. Tissues were homogenized in $1 \mathrm{ml}$ Trizol reagent and RNA extracted using a Purelink RNA Mini Kit (Life Technologies): $1.2 \mu \mathrm{g}$ RNA was used for RT-PCR using a Tetro cDNA Synthesis Kit (Bioline, Taunton, MA, USA). qPCR was conducted in $10 \mu \mathrm{l}$ reactions containing SensiFAST Probe Kit mastermix (Bioline), TaqMan target cDNA primers $(900 \mathrm{nM})$ /FAM probe $(250 \mathrm{nM})$ mix, TaqMan $18 \mathrm{~S}$ rRNA primers (50 nM), VIC probe $(200 \mathrm{nM}) \mathrm{mix}$ (Applied Biosystems), and $10 \mathrm{ng}$ cDNA. Duplicate PCRs were

Published by Bioscientifica Ltd 
performed on a 384-well plate format using a 7900 HT instrument (Applied Biosystems) with the following parameters: $5 \mathrm{~min} 95^{\circ} \mathrm{C}$ followed by 40 cycles of $95^{\circ} \mathrm{C}$ for $10 \mathrm{~s}$ and $60^{\circ} \mathrm{C}$ for $50 \mathrm{~s}$. Raw $\mathrm{Ct}$ values were normalized to internal control $18 \mathrm{~S}$ rRNA expression $(\Delta C \mathrm{t})$ and averaged. Statistical analysis was performed on $\Delta C t$ values of biological replicates, although these values were transformed to arbitrary units $\left(2^{-\Delta \Delta C t}\right)$ for graphical purposes.

\section{Protein isolation and western blot}

Approximately, 20-40 mg snap-frozen tissue was homogenized in $300 \mu \mathrm{l}$ RIPA buffer (Pierce, Rockford, IL, USA) supplemented with protease inhibitor cocktail (Roche). Proteins were quantified using a BCA Protein Assay Kit (Pierce) and denatured in $25 \mu \mathrm{l}$ reactions as follows: $25 \mu \mathrm{g}$ total protein lysate, NuPAGE LDS buffer (Life Technologies), and $5 \% \beta$-mercaptoethanol heated to $95^{\circ} \mathrm{C}$ for $5 \mathrm{~min}: 20 \mu \mathrm{g}$ denatured protein was loaded into $1 \mathrm{~mm}$, 12-well NuPAGE 4-12\% Bis-Tris gels and run in NuPAGE MES SDS buffer at $100 \mathrm{~V}$ using the XCell SureLock Mini platform (Life Technologies). Separated proteins were transferred to $0.2 \mu \mathrm{m}$ Immun-Blot PVDF membrane (BioRad) in NuPAGE Transfer buffer at $30 \mathrm{~V}$ for $2 \mathrm{~h}$ using XCell II Blot Module (Life Technologies).

The membranes were blocked for $1 \mathrm{~h}$ at room temperature (RT) under agitation in 5\% milk in PBS $0.05 \%$ Tween-20 (PBST), rinsed briefly in PBST, and incubated under agitation overnight at $5{ }^{\circ} \mathrm{C}$ in blocking buffer with $1 \mu \mathrm{g} / \mathrm{ml}$ mouse anti-11ß-HSD1 (ab83522, Abcam, Cambridge, MA, USA), or $0.4 \mu \mathrm{g} / \mathrm{ml}$ mouse anti$\beta$-actin-peroxidase-conjugated primary antibody. The membranes were washed three times for 15 min under agitation and incubated under agitation in blocking buffer with 1:5000 sheep anti-mouse IgG-peroxidase antibody (GE Healthcare, Pittsburgh, PA, USA) for $1 \mathrm{~h}$ at room temperature (step omitted for anti- $\beta$-actin-peroxidasetreated membranes). Following a further three $15 \mathrm{~min}$ PBST washes, the membranes were incubated with ECL Plus western blotting substrate for anti-human 11ß-HSD1treated membranes (Pierce), according to the manufacturer's guidelines. Proteins were visualized using a las-3000 luminescent image analyzer (FujiFilm, Stamford, CT, USA) and quantified by densitometry after normalization to $\beta$-actin (Multi Gauge v2.3). The anti-11ß-HSD1 antibody detected a band of the predicted size $(34 \mathrm{kDa})$ in mouse skin and liver (positive control tissue). These bands were neutralized by preincubating 11 $\beta$-HSD1 antibody with $2 \mu \mathrm{g} / \mathrm{ml}$ immunizing peptide of matching sequence (Abcam) for $30 \mathrm{~min}$ at RT (Supplementary Fig. 1A and B, see section on supplementary data given at the end of this article).

\section{1ß-HSD activity assays}

11ß-HSD1 (oxoreductase) Freshly isolated tissue $(20-40 \mathrm{mg})$ was incubated immediately in $1 \mathrm{ml}$ high glucose, pyruvate, and DMEM (Life Technologies) containing $100 \mathrm{nM}$ 11-DHC (Steraloids, Newport, RI, USA) with $\sim 1500$ c.p.m. of $\left[{ }^{3} \mathrm{H}\right]$ 11-DHC-generated in-house as follows:

Five $\mu \mathrm{Ci}\left[{ }^{3} \mathrm{H}\right]$ corticosterone, specific activity 70-100 Ci/mmol (Perkin Elmer, Waltham, MA, USA), $450 \mu \mathrm{g}$ homogenized mouse placenta protein (exhibiting high $11 \beta$-HSD2 activity), and $500 \mu \mathrm{M} \mathrm{NAD}^{+}$cofactor in $500 \mu \mathrm{l}$ (total volume) $0.1 \mathrm{M}$ potassium phosphate buffer pH 7.4 (Bio-World, Dublin, OH, USA) were incubated under agitation at $37^{\circ} \mathrm{C}$ for $\left.3 \mathrm{~h} .{ }^{3} \mathrm{H}\right]$ 11-DHC was extracted by vortexing in $5 \mathrm{ml}$ dichloromethane, removal of aqueous/protein phase by aspiration, and concentration under air at $55{ }^{\circ} \mathrm{C}$ for $20 \mathrm{~min} .\left[{ }^{3} \mathrm{H}\right]$ 11-DHC was resuspended in $100 \mu \mathrm{l}$ dichloromethane, spotted onto foilbacked silica plates, and separated by TLC in a $186: 14 \mathrm{ml}$ chloroform:ethanol mobile phase for $90 \mathrm{~min}$ with $10 \mathrm{mM}$ 11-DHC run in adjacent lanes. Plates were visualized under u.v. to localize 11-DHC and this area also containing $\left[{ }^{3} \mathrm{H}\right]$ 11-DHC was excised and eluted overnight in $500 \mu \mathrm{l}$ ethanol at $4{ }^{\circ} \mathrm{C}$. Ethanol concentration was adjusted to 1500 c.p.m./ $\mu \mathrm{l}$ by liquid scintillation.

$11 \beta$-HSD1 assays were incubated at $37^{\circ} \mathrm{C}$ for $16 \mathrm{~h}$ (predetermined by time course to generate $\sim 25 \%$ conversion in unwounded control samples). Subsequently, tissues were weighed and discarded and steroids were extracted and separated as described earlier (co-migrating with $10 \mathrm{mM}$ 11-DHC/corticosterone standards). Plate regions containing 11-DHC and corticosterone were excised and percentage conversion of the latter determined by liquid scintillation.

11ß-HSD2 (dehydrogenase) Freshly isolated tissue (20-40 mg) was assayed as described earlier, replacing $100 \mathrm{nM}$ 11-DHC with corticosterone and $\left[{ }^{3} \mathrm{H}\right]$ 11-DHC with $\left[{ }^{3} \mathrm{H}\right]$ corticosterone diluted 1:500 in ethanol.

\section{Immunohistochemistry}

Freshly isolated tissue was stored in Formalde-Fresh (Fisher Scientific, Pittsburgh, PA, USA) and processed into paraffin blocks. The $5 \mu \mathrm{m}$ sections were de-waxed, rehydrated, and

Published by Bioscientifica Ltd 
stained with hematoxylin and eosin (H\&E) (Leica, Buffalo Grove, IL, USA and Thermo Scientific, Kalamazoo, MI, USA) or for $11 \beta-H S D 1$ as follows: following rehydration and antigen unmasking for $20 \mathrm{~min}$ at $98^{\circ} \mathrm{C} \mathrm{pH} 6$ (Vector Labs, Burlingame, CA, USA), the sections were treated with $1 \%$ $\mathrm{H}_{2} \mathrm{O}_{2}$ (diluted in methanol) for $15 \mathrm{~min}$ at RT. Following two 5 min Tris-buffered saline (TBS) washes, slides were blocked in $4 \% \mathrm{BSA} / 0.5 \%$ cold water fish gelatin in TBS for $1 \mathrm{~h}$ at RT. Slides were rinsed twice for $2 \mathrm{~min}$ in TBS and incubated with anti-11ß-HSD1 primary antibody at $1 \mu \mathrm{g} / \mathrm{ml}$ in blocking solution for $30 \mathrm{~min}$ at RT. Primary antibody neutralized with immunizing peptide was used for negative control sections. Slides were rinsed twice for $2 \mathrm{~min}$ in TBS and incubated in biotinylated goat anti-rabbit IgG secondary antibody (1:500, Vector Labs) for $10 \mathrm{~min}$ at RT. Slides were rinsed twice for 2 min in TBS and incubated in avidin-biotin-complex (Vector Labs) for $15 \mathrm{~min}$ at RT. Following two $5 \mathrm{~min}$ TBS washes sections were incubated with DAB peroxidase substrate (Vector Labs), dehydrated, fitted with cover slips, and visualized on a Zeiss microscope (Jena, Germany) using AxioVision (Carl Zeiss Vision, Munich, Germany).

\section{Steroidogenic enzyme assay}

Freshly isolated tissue (20-40 mg skin or minced whole adrenal) was incubated immediately and processed for $11 \beta$-HSD activity assays $\left(16 \mathrm{~h}\right.$ at $\left.37^{\circ} \mathrm{C}\right)$, replacing $100 \mathrm{nM}$ 11 -DHC/corticosterone with $100 \mathrm{nM}$ progesterone and $\sim 1500$ c.p.m. of $\left[{ }^{3} \mathrm{H}\right]$ progesterone, specific activity 90-115 Ci/mmol (Perkin Elmer). Following extraction, progesterone metabolites were separated by TLC and co-migrated with $10 \mathrm{mM}$ progesterone, 11-deoxycorticosterone (11-DOC), 11-deoxycortisol (11-DOF), 11-DHC, corticosterone, and cortisol standards. Percent conversion of progesterone to these metabolites was determined by liquid scintillation.

\section{Statistical analysis}

Following confirmation of data displaying a normal distribution, significance levels were determined by twoway ANOVA using GraphPad Prism (La Jolla, CA, USA).

\section{Results}

\section{Increased 11 $\beta$-HSD1 expression and activity during wound healing}

The regulation of $11 \beta$-HSD1 (Fig. 1A) during skin wound healing has not been previously investigated. Therefore, we examined changes in 11ß-HSD1 (Hsd11b1) expression and activity following full-thickness dorsal punch biopsies in mice (wound closure occurred between day 8 and 10). $H s d 11 b 1$ expression was tenfold higher in day 2 wounds compared with unwounded control tissue $(\Delta C \mathrm{t} \pm$ s.E.M. $16.8 \pm 0.4$ vs $20.6 \pm 0.5$ respectively, $P<0.001$ ) and threefold higher in day 4 wounds $(P<0.001)$, returning to levels similar to those of unwounded by day 8 (Fig. 1B). Correspondingly, $11 \beta$-HSD1 protein expression (normalized to $\beta$-actin) was 2.5 -fold higher in day 2 wounds $(P<0.01)$ and twofold greater in day 4 wounds $(P<0.05)$ relative to unwounded control skin and was similar to that observed in unwounded skin at days 8, 14, and 21 (Fig. 1C). In contrast, $11 \beta$-HSD2 mRNA expression was low $(\Delta C \mathrm{t} \pm$ S.E.M. $23.3 \pm 0.7$ ) and unaffected by wound healing (Fig. 1B).

Although abundantly expressed, 11ß-HSD1 nicotinamide adenine dinucleotide phosphate (NADPH) cofactorsupplying enzymes, hexose-6-phosphate dehydrogenase $(\Delta C \mathrm{t} \pm$ s.E.M. $16.9 \pm 0.1)$ and $\mathrm{GC}$ receptor $(\Delta C \mathrm{t} \pm$ s.E.M. $15.8 \pm$ 0.09) mRNA, were not significantly altered during wound healing (Supplementary Fig. 2A and B, see section on supplementary data given at the end of this article). However, mRNA expression for the mineralocorticoid receptor was decreased at days $2(65 \%, P<0.01)$ and 4 (63\%, $P<0.001)$ post-wounding (Supplementary Fig. 2C), although expression was considerably lower than that of GC receptor in unwounded skin $(\Delta C \mathrm{C} \pm$ s.E.M. $20.6 \pm 0.1)$.

Consistent with these expression data, 11ß-HSD1 activity (11-DHC to corticosterone) was $>2.5$-fold higher in day 2 (pmol corticosterone/h $4.21 \pm 0.2$ vs $1.45 \pm 0.3$, $P<0.001)$ and day $4(4.4 \pm 0.3$ vs $1.45 \pm 0.5, P<0.001)$ wounds (Fig. 1D). In contrast, 11ß-HSD2 activity (corticosterone to 11-DHC) in unwounded skin was negligible (pmol 11-DHC/h <0.2) and remained unchanged postwounding (Fig. 1D).

In summary, $11 \beta-H S D 1$ is the dominant $11 \beta-H S D$ isozyme expressed in mouse skin and demonstrates increased expression and activity during early wound repair.

\section{1 $\beta$-HSD1 localizes to wound inflammatory infiltrate during wound healing}

Compared with unwounded skin (Fig. 2A), H\&E histology revealed a large influx of inflammatory cells at day 2 (Fig. 2C) and 4 (Fig. 2F), which diminished by day 8 when fibroblasts became more abundant (Fig. 2H). These inflammatory cells were largely undetectable in day 14 (Fig. 2J) and day 21 (Fig. 2L) wounds. In unwounded skin, 11ß-HSD1 was expressed in keratinocytes, fibroblasts, hair follicles, and sebaceous glands (Fig. 2B) as previously

Published by Bioscientifica Ltd. 
A

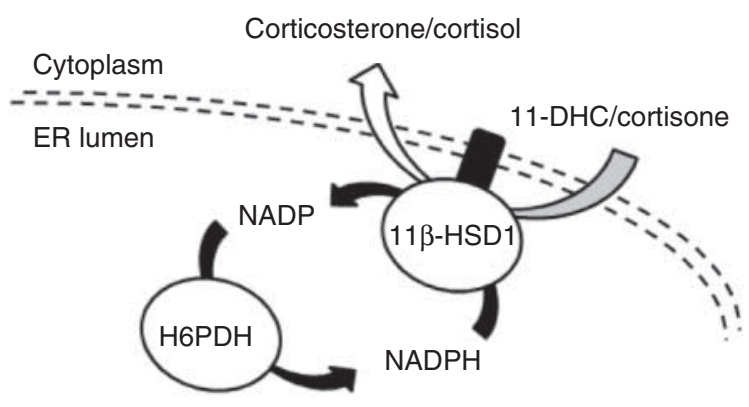

C
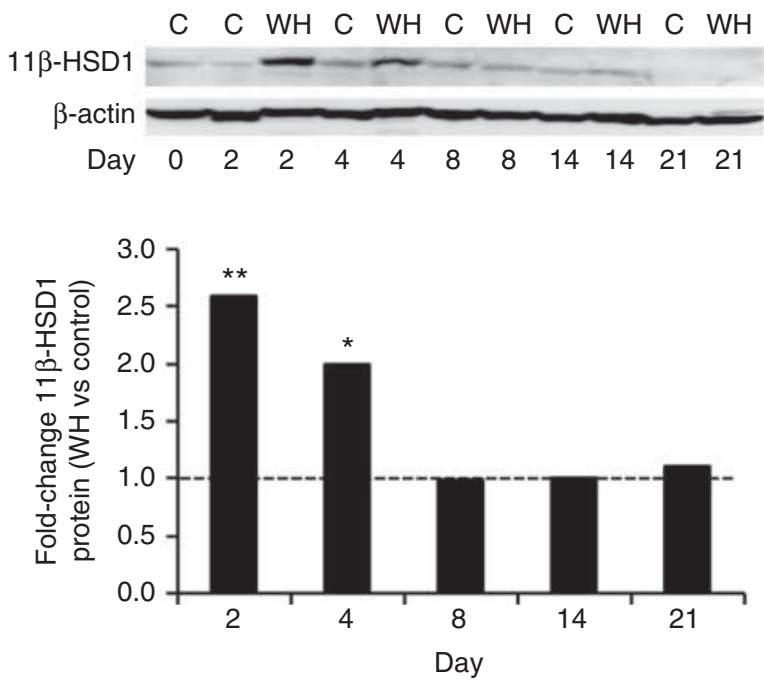

B

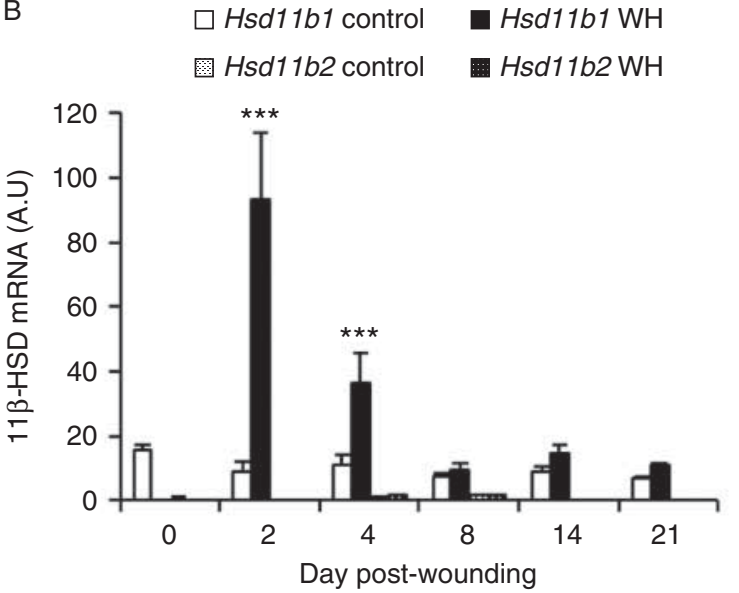

D

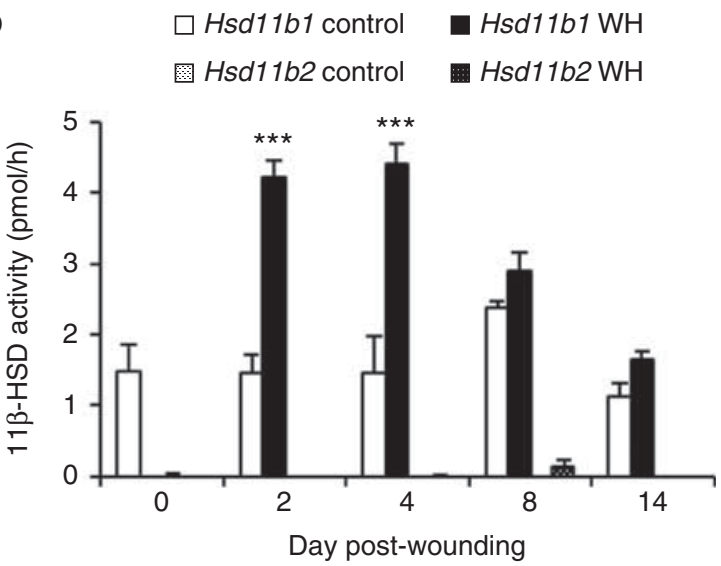

(B) 11ß-HSD (Hsd11b1 and Hsd11b2) mRNA expression during wound healing (WH; normalized to 185 rRNA) compared with expression in control (unwounded) skin ( $n=4-14$ ). (C) 11 $\beta$-HSD1 protein expression (34 kDa) normalized to $\beta$-actin $(42 \mathrm{kDa})$ during wound healing compared with control (C, $n=5)$. (D) $11 \beta$-HSD activity during wound healing compared with control $(n=4) .{ }^{*} P<0.05, * * P<0.01, * * * P<0.001$.

with 11ß-HSD1-positive staining of a similar intensity to unwounded skin (Fig. 2K). This remained the case at 21 days post-wounding (Fig. 2M), where further collagen remodeling was evident with the reappearance of dermal appendages such as hair follicles and sebaceous glands. The H\&E and 11 $\beta$-HSD1 immunostaining are presented at a lower magnification as an additional Supplementary Fig. 3A, B, C, D, E, F, G, H, I, J, K, and L, see section on supplementary data given at the end of this article.

\section{Steroidogenic enzyme expression during wound healing}

Similar to $11 \beta$-HSDs, changes in steroidogenic enzyme expression during wound healing have not been http://joe.endocrinology-journals.org DOI: 10.1530/JOE-13-0420
(C) 2014 Society for Endocrinology Printed in Great Britain 

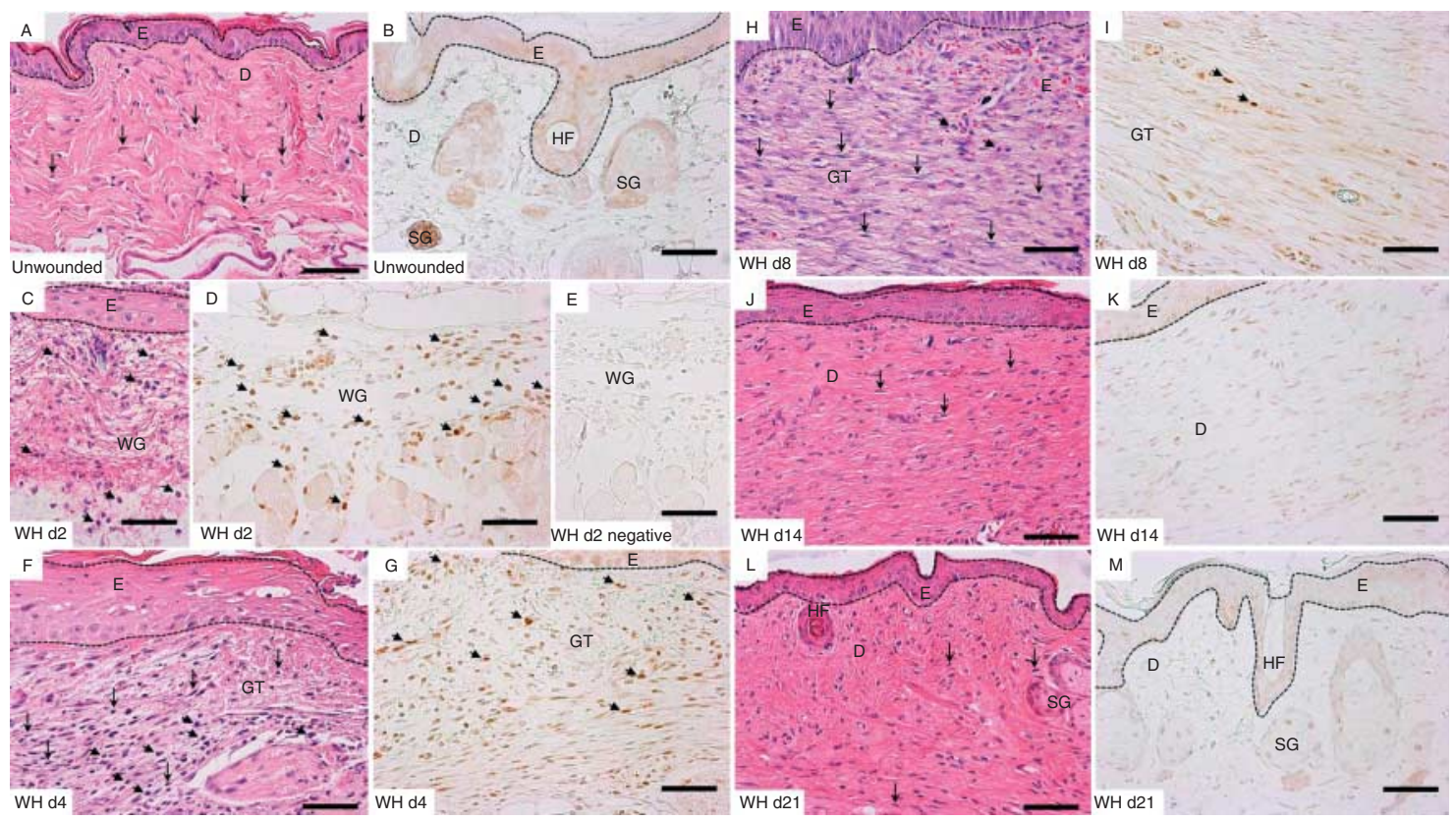

\section{Figure 2}

$11 \beta$-hydroxysteroid dehydrogenase type 1 (11ß-HSD1) protein localizes to infiltrating inflammatory cells during wound healing. H\&E staining of unwounded mouse skin (A) and showing inflammatory ( $C$ and $F$ ), granulation $(\mathrm{F}$ and $\mathrm{H})$ and remodeling $(\mathrm{J}$ and $\mathrm{L})$ stages of wound healing. 11ß-HSD1-positive staining localized to epidermal keratinocytes (E), fibroblasts (long arrows), hair follicles (HF), and sebaceous glands (SG) in unwounded skin (B). 11ß-HSD1 staining was greatest in day 2 wounds

investigated in detail. Therefore, we analyzed mRNA levels for six key enzymes required for sequential conversion of cholesterol to corticosterone/cortisol (Fig. 3A). Expression of the mitochondrial cholesterol transporter StAR, regarded as the rate-limiting step in steroid biosynthesis, was modestly elevated in day 4 wounds $(P<0.05$, Fig. 3B), but overall expression was considerably lower than that observed in adrenal gland (Supplementary Fig. 4A, see section on supplementary data given at the end of this article). Expression of cholesterol side-chain cleavage enzyme (CYP11A1), which converts cholesterol to pregnenolone, was variable, with trends toward decreased expression in day 2 wounds and increased expression in day 14 wounds (Fig. 3C).

Subsequent conversion of pregnenolone to progesterone is conducted by $3 \beta$-hydroxysteroid dehydrogenase type 6 (3ß-HSD6), expression of which was also variable during wound healing (Fig. 3D). Alternatively, pregnenolone and progesterone conversion to the sex steroid and cortisol precursors $17 \alpha$-hydroxypregnenolone/ progesterone is catalyzed by $17 \alpha$-hydroxylase (CYP17), which displayed $>50 \%$ decreased expression in day 2 and localizing largely to the inflammatory cell infiltrate (D, arrowheads) in the wound gap (WG). Staining was negligible in sections incubated with primary antibody pre-adsorbed with immunizing peptide (E). Positively staining cells were reduced in granulation tissue (GT) of day 4 wounds (G) and still further by day $8(\mathrm{I})$. Staining remained low during later stages of dermal remodeling $(K)$ and similar to that for unwounded skin at day $21(M)$. D, dermis, representative images $(n=4)$, scale bars $50 \mu \mathrm{m}$.

4 wounds $(P<0.05$, Fig. 3E). This reaction is lacking in mouse adrenals due to the absence of appreciable $C y p 17 a 1$ expression (Supplementary Fig. 4A).

Interestingly, expression of the 21-hydroxylase (CYP21A1), which converts progesterone and $17 \alpha$ progesterone to GC precursors 11-DOC and 11-DOF, was increased 25- and fivefold in day 2 and 4 wounds respectively $(P<0.001$, Fig. $3 F)$. However, expression of the final enzyme in the GC synthesis pathway, 11ßhydroxylase (CYP11B1), required for conversion of these precursors to corticosterone and cortisol respectively was undetectable (Supplementary Fig. 4A). Expression of CYP11B2, which converts 11-DOC to the mineralocorticoid receptor (MR) ligand aldosterone, was also undetectable in unwounded mouse skin or during wound healing (Supplementary Fig. 4A).

Although steroidogenic enzyme mRNA expression exhibited a mixed regulatory profile during wound healing, expression of all except $C y p 17 a 1$ was considerably lower in skin than in the adrenal glands. Importantly, the lack of $C y p 11 b 1$ expression indicates that this pathway is unable to synthesize GC de novo in murine skin.

Published by Bioscientifica Ltd 
A
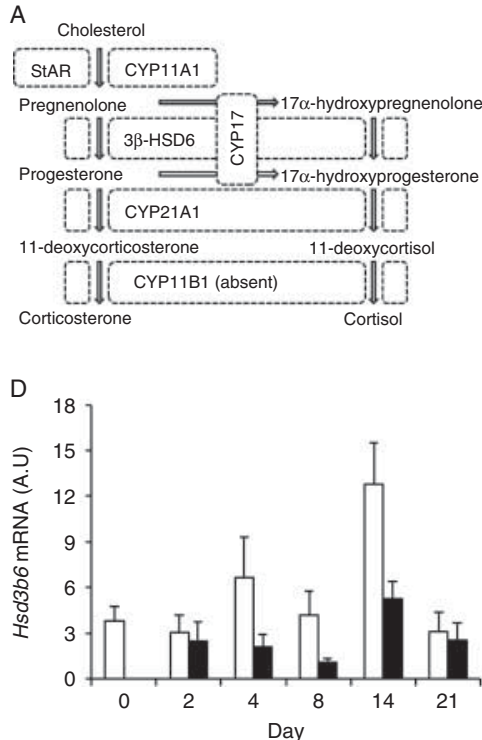

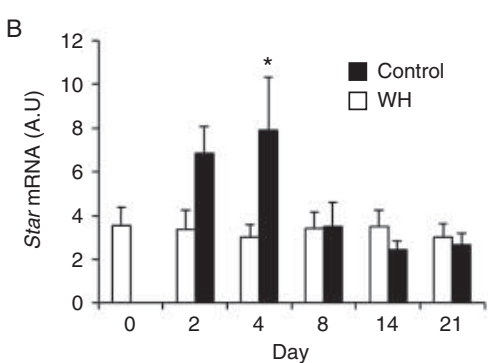

E

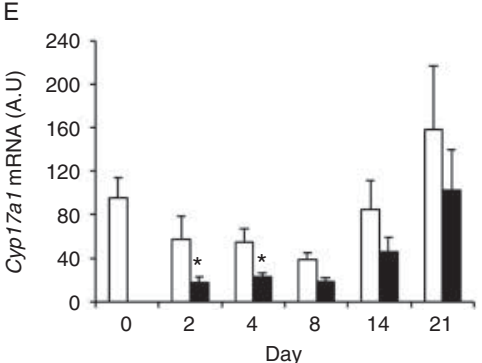

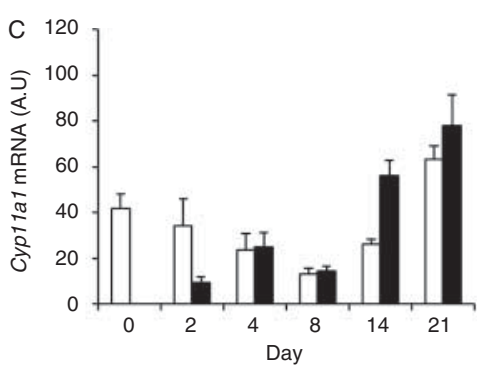

$\mathrm{F}$

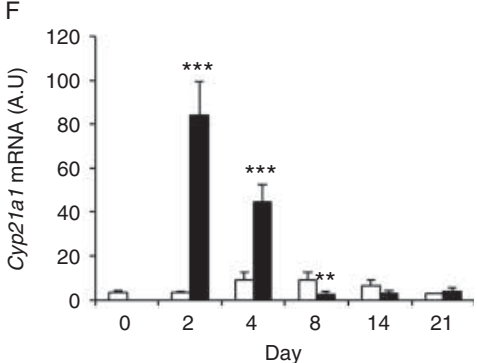

\section{Figure 3}

Steroidogenic enzyme expression during wound healing. (A) Schematic representation of the steroidogenic pathway in mouse skin. (B) mRNA expression during wound healing (normalized to $18 \mathrm{~S}$ rRNA) for StAR, (C) cholesterol side-chain cleavage enzyme (CYP11A1),

\section{Steroidogenic enzyme activity during wound healing}

Steroidogenic enzyme activity was determined by incubation with radiolabeled progesterone and analysis of downstream steroid (corticosterone and cortisol) and steroid precursor (11-DOC, 11-DOF, and 11-DHC) metabolites. Corticosterone was the progesterone metabolite detectable at the lowest levels in skin and was largely unaffected by wound healing, supporting our findings indicating a lack of $C y p 11 b 1$ expression (Fig. 4A). Indeed, corticosterone levels appeared lower that the levels of cortisol used as a negative control. In skin, 11-DOC, 11-DOF, and 11-DHC were the dominant progesteronederived metabolites in contrast to mouse adrenals where, as anticipated, corticosterone was the principal progesterone metabolite (Supplementary Fig. 4B). Moreover, wound healing appeared to decrease corticosteroidogenesis in skin with reduced 11-DOC and 11-DOF metabolites at days 2 and 4 (Fig. 4A), the former also correlating with lower Cyp17a1 expression.

Finally, comparison of corticosterone generation from progesterone (by steroidogenesis) or from 11-DHC (by 11 -HSD1) demonstrates that the latter generates considerably more corticosterone in unwounded skin and post-wounding (Fig. 4B). This difference is probably underestimated as our analysis assumed complete conversion of radiolabeled progesterone to the metabolites

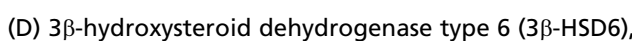
(E) 17 $\alpha$-hydroxylase/17, 20 lyase (CYP17), and (F) 21-hydroxylase (CYP21A1, $n=4-14)$. ${ }^{*} P<0.05, * * P<0.01, * * * P<0.001$.

analyzed; in fact only $\sim 25 \%$ was recovered (Supplementary Fig. 5A, see section on supplementary data given at the end of this article) while radiolabeled 11-DHC recovery was considerably greater (Supplementary Fig. 5B).

\section{Discussion}

Despite the adverse effects of GC on wound healing being well documented, changes in local GC synthesis and metabolism during this process remained, until recently, largely unexplored. Early studies demonstrated increased conversion of cortisone to cortisol during the inflammatory phase of wound healing in mouse skin (Nabors \& Berliner 1969). Although these experiments preceded the current understanding of $11 \beta$-HSD enzyme functions, they proffered evidence for a possible role of GC metabolism in wound repair.

In this study, we demonstrate increased GC-activating $11 \beta$-HSD1 expression and activity during the initial phases of wound healing in mouse skin. This finding explains the early observations cited earlier and underpins recent observations by us and others demonstrating accelerated wound healing following topical 11 -HSD1 inhibitor treatment in young mice and in aged 11 -HSD1 KO mice, despite elevated circulating corticosterone levels (Terao et al. 2011, Tiganescu et al. 2013). The lack of

Published by Bioscientifica Ltd 

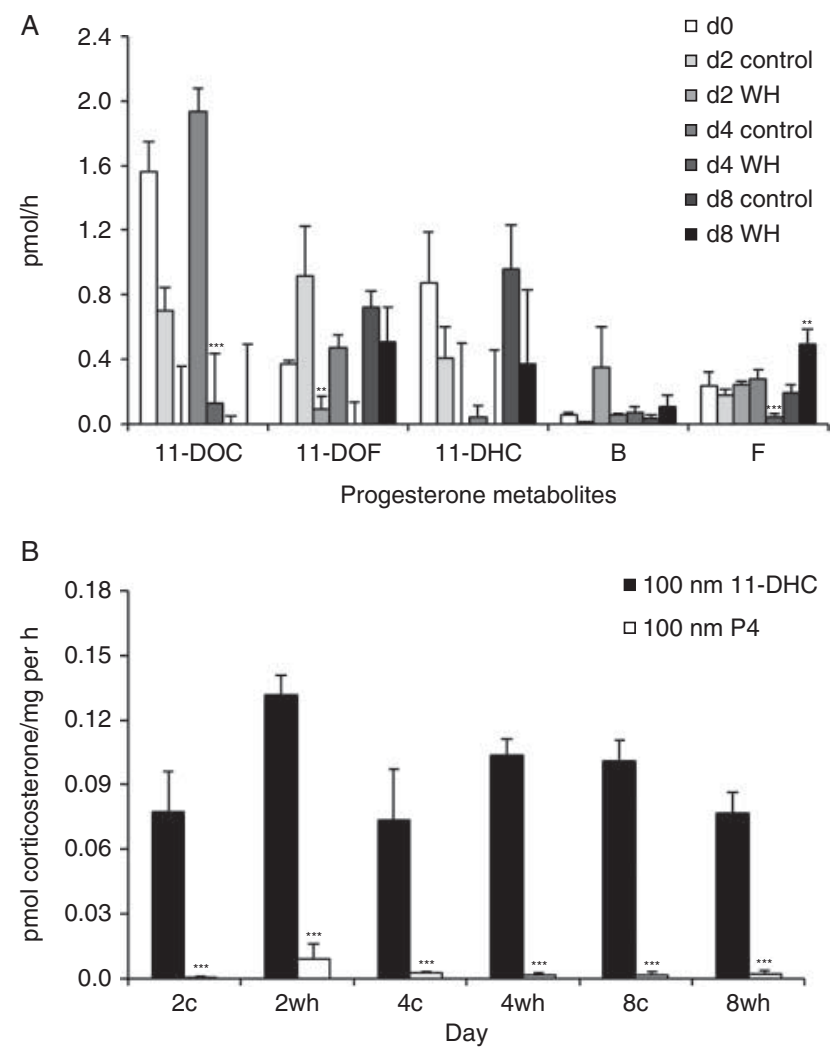

Figure 4

Steroidogenic synthesis of corticosterone compared with activation by $11 \beta$-hydroxysteroid dehydrogenase type 1 (11 -HSD1) during wound healing. (A) Steroidogenic conversion of $100 \mathrm{nM}$ progesterone to 11-deoxycorticosterone (11-DOC), 11-deoxycortisol (11-DOF),

11-dehydrocorticosterone (11-DHC), corticosterone (B), and cortisol $(\mathrm{F}$, negative control) during wound healing $(\mathrm{WH}, n=4)$. (B) Corticosterone generation from 11-DHC (11 $\beta$-HSD1 substrate) compared with generation from progesterone (P4) in wounded (wh) and control (c) skin $(n=4)$. $* P<0.05, * * P<0.01, * * * P<0.001$.

Hsd11b2 expression is consistent with results from a previous study (Tiganescu et al. 2011).

The immunohistochemistry data presented here indicate that the elevated 11ß-HSD1 activity during wound healing derives from numerous inflammatory cells that infiltrate the tissue immediately following wounding. Although not previously investigated in the context of wound healing, 11ß-HSD1 expression and activity in murine lymphocytes have been reported and postulated to prevent the development of excessive inflammation (Zhang et al. 2005). 11ß-HSD1 has also been reported to regulate mouse macrophage phagocytosis (Gilmour et al. 2006), human neutrophil survival (Kardon et al. 2008), and murine mast cell degranulation (Coutinho et al. 2013), although the beneficial/adverse effects of 11 $\beta$-HSD1 blockade in various models of inflammation are still under debate (Chapman et al. 2013, Hardy et al. 2013).
Interestingly, limiting GC levels accelerated skin wound healing despite increased pro-inflammatory IL1 $\beta$ expression (Vukelic et al. 2011), indicating that the adverse effects of GC activation during wound healing may outweigh beneficial anti-inflammatory functions.

Although significantly lower than glucocorticoid receptor (GR), MR expression was decreased during wound healing possibly as a negative-feedback mechanism in response to increased availability of GC (which also binds MR with high affinity). Similar abnormalities in skin barrier development have been reported for GR- and MR-overexpressing mouse models (Pérez et al. 2001, Sainte Marie et al. 2007); therefore, dissociating GR/MR-mediated effects of GC excess in skin would be of interest in future studies.

Several steroidogenic enzymes have previously been identified in rodent skin (Abbaszade et al. 1997, Slominski et al. 2004), supporting our finding that all except CYP11B1 are expressed at the mRNA level in mouse skin. Accordingly, we observed an accumulation of 11-DOC and 11-DOF progesterone metabolites consistent with their impaired metabolism to GC (due to lack of Cyp11b1), with other studies also reporting a lack of pregnenolone metabolism to corticosterone in rodent skin (Dalla Valle et al. 1992). In the absence of $C y p 11 b 1$, the low levels of corticosterone metabolized from progesterone could be derived from 11-DHC (11 $\beta$-HSD1 substrate), also reported by others to be the dominant progesterone metabolite in rodent skin (Slominski et al. 2000a). Furthermore, although Cyp17a1 and Cyp21a1 were decreased and increased respectively during wound healing, Cyp11b2 expression was also lacking in mouse skin, precluding aldosterone synthesis from 11-DOC. However, as Cyp17a1 expression was readily detected in mouse skin, sex steroid metabolism from progesterone remains a possibility.

The data presented here compare de novo GC synthesis and GC activation by $11 \beta-H S D 1$ as sources of GC generation in unwounded mouse skin and during wound healing. Recent findings have indicated that both mechanisms contribute to local GC levels and a large body of evidence supports the hypothesis that human skin is capable of generating appreciable levels of GC through steroidogenesis (reviewed in Slominski et al. 2012). However, here we demonstrate that the contribution made by steroidogenesis in mouse skin is negligible compared with GC activation by $11 \beta$-HSD1, which generates corticosterone at concentrations capable of GR activation (Dong et al. 2006). Furthermore, while 11 $\beta$-HSD1 expression and activity increase during wound healing, corticosteroidogenic enzymes display variable mRNA regulation but decreased activity. The latter may be due to increased progesterone

Published by Bioscientifica Ltd. 
clearance to steroid metabolites not analyzed (i.e., sex steroids) or to water-soluble metabolites discarded during the steroid extraction process.

Recently, a study using human and porcine models has indicated that steroidogenesis contributes directly to increased GC levels generated during wound healing (Vukelic et al. 2011). This study demonstrated that inhibition of cortisol synthesis and acceleration of wound healing following metyrapone and IGF1 treatment suggested to act through inhibition of CYP11B1 activity and expression respectively. However, both treatments are also known 11ß-HSD1 inhibitors (Stewart et al. 2001, Hellmich et al. 2013), indeed metyrapone-mediated inhibition of $11 \beta$-HSD1 is postulated to contribute to improved memory consolidation and retrieval in rodent studies (Hellmich et al. 2013). Furthermore, GH-deficient (and subsequently IGF1-deficient) patients exhibit increased global 11ß-HSD1 activity (Weaver et al. 1994) and a skin phenotype characterized by epidermal thinning (Lange et al. 2001). This is also a common phenotype of aged skin, which we found to display elevated 11ß-HSD1 activity in both humans and mice (Tiganescu et al. 2013) while circulating GH/IGF1 levels are also known to decline with advancing age. It is therefore possible that the accelerated healing induced by IGF1 and metyrapone treatment (Vukelic et al. 2011) was due to inhibition of 11ß-HSD1 rather than CYP11B1.

It is important to emphasize that differences in skin endocrine pathways do exist between mice and man, including for CRH and proopiomelanocortin (Slominski et al. 2000b) in addition to $11 \beta$-HSD2 and CYP11B1 which are expressed in human skin (Brown et al. 1996, Hannen et al. 2011). Although our studies were conducted in mice, the ability of human skin to synthesize cortisol de novo also remains debatable, with studies reporting both negative (Slominski et al. 2002) and positive findings (Cirillo \& Prime 2011, Hannen et al. 2011, Vukelic et al. 2011). Moreover, the quantities of cortisol generated de novo in these studies appear to be considerably lower than those reported to be generated by $11 \beta-H S D 1$ in human skin (Tiganescu et al. 2011, 2013).

Several clinical trials using selective $11 \beta$-HSD1 inhibitors as therapies for obesity-related diabetes mellitus have reported positive outcomes (Feig et al. 2011, Gibbs et al. 2011, Hollis \& Huber 2011, Liu et al. 2011, Park et al. 2012). Local 11ß-HSD1 blockade could be particularly effective in accelerating wound repair in older patients, whereas elevated 11ß-HSD1 activity in skin (Tiganescu et al. 2011, 2013) is coupled to slower healing and delayed but prolonged inflammation (Ashcroft et al. 1997,
Brubaker et al. 2013). 11ß-HSD1 levels were also found to be elevated in the lymphocytes of aged mice (Zhang et al. 2005). In the elderly, a vicious cycle of increased local GC activation and decreased GC sensitivity (Wilkinson et al. 1997, Rohleder et al. 2002) may contribute to blunted diurnal cortisol secretion patterns (Van Cauter et al. 1996) and 'inflamm-aging' (Shaw et al. 2010). Given the restoration of normal wound healing capacities by GRinhibitor (RU486) treatment in GC-impaired and diabetic wound models (Bitar 2000), the involvement of 11ß-HSD1 in the etiology of chronic diabetic wounds also remains an exciting prospect.

\section{Supplementary data}

This is linked to the online version of the paper at http://dx.doi.org/10.1530/ JOE-13-0420.

\section{Declaration of interest}

The authors declare that there is no conflict of interest that could be perceived as prejudicing the impartiality of the research reported.

\section{Funding}

This work was supported by the Department of Defence (grant number W81XWH-11-2-0189) to P M E.

\section{References}

Abbaszade IG, Arensburg J, Park CH, Kasa-Vubu JZ, Orly J \& Payne AH 1997 Isolation of a new mouse $3 \beta$-hydroxysteroid dehydrogenase isoform, 3 $\beta$-HSD VI, expressed during early pregnancy. Endocrinology 138 1392-1399. (doi:10.1210/endo.138.4.5042)

Agarwal AK, Monder C, Eckstein B \& White PC 1989 Cloning and expression of rat cDNA encoding corticosteroid $11 \beta$-dehydrogenase. Journal of Biological Chemistry 264 18939-18943.

Ashcroft GS, Horan MA \& Ferguson MW 1997 Aging is associated with reduced deposition of specific extracellular matrix components, an upregulation of angiogenesis, and an altered inflammatory response in a murine incisional wound healing model. Journal of Investigative Dermatology 108 430-437. (doi:10.1111/1523-1747.ep12289705)

Bitar MS 2000 Insulin and glucocorticoid-dependent suppression of the IGF-I system in diabetic wounds. Surgery 127 687-695. (doi:10.1067/ msy.2000.105869)

Brauchle M, Fassler R \& Werner S 1995 Suppression of keratinocyte growth factor expression by glucocorticoids in vitro and during wound healing. Journal of Investigative Dermatology 105 579-584. (doi:10.1111/ 1523-1747.ep12323521)

Brown RW, Chapman KE, Kotelevtsev Y, Yau JL, Lindsay RS, Brett L, Leckie C, Murad P, Lyons V, Mullins JJ et al. 1996 Cloning and production of antisera to human placental 11 $\beta$-hydroxysteroid dehydrogenase type 2 . Biochemical Journal 313 1007-1017.

Brubaker AL, Rendon JL, Ramirez L, Choudhry MA \& Kovacs EJ 2013 Reduced neutrophil chemotaxis and infiltration contributes to delayed resolution of cutaneous wound infection with advanced age. Journal of Immunology 190 1746-1757. (doi:10.4049/jimmunol.1201213) 
Chapman KE, Coutinho AE, Zhang Z, Kipari T, Savill JS \& Seckl JR 2013 Changing glucocorticoid action: $11 \beta$-hydroxysteroid dehydrogenase type 1 in acute and chronic inflammation. Journal of Steroid Biochemistry and Molecular Biology 137 82-92. (doi:10.1016/j.jsbmb.2013.02.002)

Chedid M, Hoyle JR, Csaky KG \& Rubin JS 1996 Glucocorticoids inhibit keratinocyte growth factor production in primary dermal fibroblasts. Endocrinology 137 2232-2237. (doi:10.1210/endo.137.6.8641170)

Cirillo N \& Prime SS 2011 Keratinocytes synthesize and activate cortisol. Journal of Cellular Biochemistry 112 1499-1505. (doi:10.1002/jcb.23081)

Cooper MS \& Stewart PM 2009 11ß-hydroxysteroid dehydrogenase type 1 and its role in the hypothalamus-pituitary-adrenal axis, metabolic syndrome, and inflammation. Journal of Clinical Endocrinology and Metabolism 94 4645-4654. (doi:10.1210/jc.2009-1412)

Coutinho AE, Brown JK, Yang F, Brownstein DG, Gray M, Seckl JR, Savill JS \& Chapman KE 2013 Mast cells express 11ß-hydroxysteroid dehydrogenase type 1: a role in restraining mast cell degranulation. PLOS ONE $\mathbf{8}$ e54640. (doi:10.1371/journal.pone.0054640)

Dalla Valle L, Belvedere P, Simontacchi C \& Colombo L 1992 Extraglandular hormonal steroidogenesis in aged rats. Journal of Steroid Biochemistry and Molecular Biology 43 1095-1098. (doi:10.1016/09600760(92)90337-I)

Dong DD, Jewell CM, Bienstock RJ \& Cidlowski JA 2006 Functional analysis of the LXXLL motifs of the human glucocorticoid receptor: association with altered ligand affinity. Journal of Steroid Biochemistry and Molecular Biology 101 106-117. (doi:10.1016/j.jsbmb.2006.06.010)

Feig PU, Shah S, Hermanowski-Vosatka A, Plotkin D, Springer MS, Donahue S, Thach C, Klein EJ, Lai E \& Kaufman KD 2011 Effects of an 11ß-hydroxysteroid dehydrogenase type 1 inhibitor, MK-0916, in patients with type 2 diabetes mellitus and metabolic syndrome. Diabetes, Obesity and Metabolism 13 498-504. (doi:10.1111/j.14631326.2011.01375.x)

Frank S, Madlener M \& Werner S 1996 Transforming growth factors $\beta 1, \beta 2$, and $\beta 3$ and their receptors are differentially regulated during normal and impaired wound healing. Journal of Biological Chemistry 271 10188-10193. (doi:10.1074/jbc.271.17.10188)

Gibbs JP, Emery MG, McCaffery I, Smith B, Gibbs MA, Akrami A, Rossi J, Paweletz K, Gastonguay MR, Bautista E et al. 2011 Population pharmacokinetic/pharmacodynamic model of subcutaneous adipose

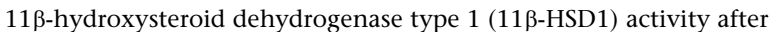
oral administration of AMG 221, a selective 11 $\beta$-HSD1 inhibitor. Journal of Clinical Pharmacology 51 830-841. (doi:10.1177/ 0091270010374470)

Gilmour JS, Coutinho AE, Cailhier JF, Man TY, Clay M, Thomas G, Harris HJ, Mullins JJ, Seckl JR, Savill JS et al. 2006 Local amplification of glucocorticoids by $11 \beta$-hydroxysteroid dehydrogenase type 1 promotes macrophage phagocytosis of apoptotic leukocytes. Journal of Immunology 176 7605-7611.

Hannen RF, Michael AE, Jaulim A, Bhogal R, Burrin JM \& Philpott MP 2011 Steroid synthesis by primary human keratinocytes; implications for skin disease. Biochemical and Biophysical Research Communications 404 62-67. (doi:10.1016/j.bbrc.2010.11.059)

Hardy RS, Seibel MJ \& Cooper MS 2013 Targeting 11ß-hydroxysteroid dehydrogenases: a novel approach to manipulating local glucocorticoid levels with implications for rheumatic disease. Current Opinion in Pharmacology 13 440-444. (doi:10.1016/j.coph.2013.03.003)

Hellmich HL, Rojo DR, Micci MA, Sell SL, Boone DR, Crookshanks JM, DeWitt DS, Masel BE \& Prough DS 2013 Pathway analysis reveals common pro-survival mechanisms of metyrapone and carbenoxolone after traumatic brain injury. PLoS ONE 8 e53230. (doi:10.1371/journal. pone.0053230)

Hollis G \& Huber R 2011 11 $\beta$-Hydroxysteroid dehydrogenase type 1 inhibition in type 2 diabetes mellitus. Diabetes, Obesity and Metabolism 13 1-6. (doi:10.1111/j.1463-1326.2010.01305.x)

Ito N, Ito T, Kromminga A, Bettermann A, Takigawa M, Kees F, Straub RH \& Paus R 2005 Human hair follicles display a functional equivalent of the hypothalamic-pituitary-adrenal axis and synthesize cortisol. FASEB Journal 19 1332-1334. (doi:10.1096/fj.04-1968fje)

Kardon T, Senesi S, Marcolongo P, Legeza B, Bánhegyi G, Mandl J, Fulceri R \& Benedetti A 2008 Maintenance of luminal NADPH in the endoplasmic reticulum promotes the survival of human neutrophil granulocytes. FEBS Letters 582 1809-1815. (doi:10.1016/j.febslet.2008. 04.045)

Lakshmi V \& Monder C 1988 Purification and characterization of the corticosteroid $11 \beta$-dehydrogenase component of the rat liver $11 \beta$ hydroxysteroid dehydrogenase complex. Endocrinology 123 2390-2398. (doi:10.1210/endo-123-5-2390)

Lange M, Thulesen J, Feldt-Rasmussen U, Skakkebaek NE, Vahl N, Jørgensen JO, Christiansen JS, Poulsen SS, Sneppen SB \& Juul A 2001 Skin morphological changes in growth hormone deficiency and acromegaly. European Journal of Endocrinology 145 147-153. (doi:10.1530/eje.0.1450147)

Lee B, Vouthounis C, Stojadinovic O, Brem H, Im M \& Tomic-Canic M 2005 From an enhanceosome to a repressosome: molecular antagonism between glucocorticoids and EGF leads to inhibition of wound healing. Journal of Molecular Biology 345 1083-1097. (doi:10.1016/j.jmb.2004. 11.027)

Liu J, Wang L, Zhang A, Di W, Zhang X, Wu L, Yu J, Zha J, Lv S, Cheng P et al. 2011 Adipose tissue-targeted 11 $\beta$-hydroxysteroid dehydrogenase type 1 inhibitor protects against diet-induced obesity. Endocrinology Journal 58 199-209. (doi:10.1507/endocrj.K10E-318)

Nabors CJ Jr \& Berliner DL 1969 Corticosteroid metabolism during wound healing. Journal of Investigative Dermatology 52 465-473. (doi:10.1038/ jid.1969.79)

Park JS, Rhee SD, Jung WH, Kang NS, Kim HY, Kang SK, Ahn JH \& Kim KY 2012 Anti-diabetic and anti-adipogenic effects of a novel selective $11 \beta$-hydroxysteroid dehydrogenase type 1 inhibitor in the diet-induced obese mice. European Journal of Pharmacology 691 19-27. (doi:10.1016/ j.ejphar.2012.06.024)

Pérez P, Page A, Bravo A, Del Río M, Giménez-Conti I, Budunova I, Slaga TJ \& Jorcano JL 2001 Altered skin development and impaired proliferative and inflammatory responses in transgenic mice overexpressing the glucocorticoid receptor. FASEB Journal 15 2030-2032. (doi:10.1096/fj.00-0772fje)

Quinkler M \& Stewart PM 2003 Hypertension and the cortisol-cortisone shuttle. Journal of Clinical Endocrinology and Metabolism 88 2384-2392. (doi:10.1210/jc.2003-030138)

Rohleder N, Kudielka BM, Hellhammer DH, Wolf JM \& Kirschbaum C 2002 Age and sex steroid-related changes in glucocorticoid sensitivity of proinflammatory cytokine production after psychosocial stress. Journal of Neuroimmunology 126 69-77. (doi:10.1016/S0165-5728(02)00062-0)

Sainte Marie Y, Toulon A, Paus R, Maubec E, Cherfa A, Grossin M, Descamps V, Clemessy M, Gasc JM, Peuchmaur M et al. 2007 Targeted skin overexpression of the mineralocorticoid receptor in mice causes epidermal atrophy, premature skin barrier formation, eye abnormalities, and alopecia. American Journal of Pathology 171 846-860. (doi:10.2353/ajpath.2007.060991)

Shaw AC, Joshi S, Greenwood H, Panda A \& Lord JM 2010 Aging of the innate immune system. Current Opinion in Immunology 22 507-513. (doi:10.1016/j.coi.2010.05.003)

Slominski A, Ermak G \& Mihm M 1996 ACTH receptor, CYP11A1, CYP17 and CYP21A2 genes are expressed in skin. Journal of Clinical Endocrinology and Metabolism 81 2746-2749. (doi:10.1210/jcem.81.7.8675607)

Slominski A, Gomez-Sanchez CE, Foecking MF \& Wortsman J $2000 a$ Active steroidogenesis in the normal rat skin. Biochimica et Biophysica Acta 1474 1-4. (doi:10.1016/S0304-4165(99)00215-9)

Slominski A, Wortsman J, Luger T, Paus R \& Solomon S $2000 b$ Corticotropin releasing hormone and proopiomelanocortin involvement in the cutaneous response to stress. Physiological Reviews $\mathbf{8 0}$ 979-1020.

Slominski A, Wortsman J, Foecking MF, Shackleton C, Gomez-Sanchez C \& Szczesniewski A 2002 Gas chromatography/mass spectrometry characterization of corticosteroid metabolism in human immortalized 
keratinocytes. Journal of Investigative Dermatology 118 310-315. (doi:10.1046/j.0022-202x.2001.01648.x)

Slominski A, Zjawiony J, Wortsman J, Semak I, Stewart J, Pisarchik A, Sweatman T, Marcos J, Dunbar C \& Tuckey R 2004 A novel pathway for sequential transformation of 7-dehydrocholesterol and expression of the P450scc system in mammalian skin. European Journal of Biochemistry 271 4178-4188. (doi:10.1111/j.1432-1033.2004.04356.x)

Slominski A, Zbytek B, Szczesniewski A, Semak I, Kaminski J, Sweatman T \& Wortsman J 2005a CRH stimulation of corticosteroids production in melanocytes is mediated by ACTH. American Journal of Physiology. Endocrinology and Metabolism 288 E701-E706. (doi:10.1152/ajpendo. 00519.2004)

Slominski A, Zbytek B, Semak I, Sweatman T \& Wortsman J 2005b CRH stimulates POMC activity and corticosterone production in dermal fibroblasts. Journal of Neuroimmunology 162 97-102. (doi:10.1016/ j.jneuroim.2005.01.014)

Slominski A, Zbytek B, Szczesniewski A \& Wortsman J 2006 Cultured human dermal fibroblasts do produce cortisol. Journal of Investigative Dermatology 126 1177-1178. (doi:10.1038/sj.jid.5700204)

Slominski AT, Zmijewski MA, Skobowiat C, Zbytek B, Slominski RM \& Steketee JD 2012 Sensing the environment: regulation of local and global homeostasis by the skin's neuroendocrine system. Advances in Anatomy, Embryology and Cell Biology 212 1-115.

Stewart PM, Toogood AA \& Tomlinson JW 2001 Growth hormone, insulin-like growth factor-I and the cortisol-cortisone shuttle. Hormone Research 56(Suppl 1) 1-6. (doi:10.1159/000048126)

Terao M, Murota H, Kimura A, Kato A, Ishikawa A, Igawa K, Miyoshi E \& Katayama I 2011 11ß-Hydroxysteroid dehydrogenase-1 is a novel regulator of skin homeostasis and a candidate target for promoting tissue repair. PLoS ONE 6 e25039. (doi:10.1371/journal.pone.0025039)

Tiganescu A, Walker EA, Hardy RS, Mayes AE \& Stewart PM 2011 Localization, age- and site-dependent expression, and regulation of 11ß-hydroxysteroid dehydrogenase type 1 in skin. Journal of Investigative Dermatology 131 30-36. (doi:10.1038/jid.2010.257)

Tiganescu A, Tahrani AA, Morgan SA, Otranto M, Desmoulière A, Abrahams L, Hassan-Smith Z, Walker EA, Rabbitt EH, Cooper MS et al. 2013 11ß-Hydroxysteroid dehydrogenase blockade prevents ageinduced skin structure and function defects. Journal of Clinical Invesigation 123 3051-3060. (doi:10.1172/JCI64162)

Tomlinson JW, Walker EA, Bujalska IJ, Draper N, Lavery GG, Cooper MS, Hewison M \& Stewart PM 2004 11ß-hydroxysteroid dehydrogenase type 1: a tissue-specific regulator of glucocorticoid response. Endocrine Reviews 25 831-866. (doi:10.1210/er.2003-0031)

Van Cauter E, Leproult R \& Kupfer DJ 1996 Effects of gender and age on the levels and circadian rhythmicity of plasma cortisol. Journal of Clinical Endocrinology and Metabolism 81 2468-2473. (doi:10.1210/jcem.81.7. 8675562)

Vukelic S, Stojadinovic O, Pastar I, Rabach M, Krzyzanowska A, Lebrun E, Davis SC, Resnik S, Brem H \& Tomic-Canic M 2011 Cortisol synthesis in epidermis is induced by IL-1 and tissue injury. Journal of Biological Chemistry 286 10265-10275. (doi:10.1074/jbc. M110.188268)

Weaver JU, Thaventhiran L, Noonan K, Burrin JM, Taylor NF, Norman MR \& Monson JP 1994 The effect of growth hormone replacement on cortisol metabolism and glucocorticoid sensitivity in hypopituitary adults. Clinical Endocrinology 41 639-648. (doi:10.1111/j.1365-2265. 1994.tb01830.x)

Wilkinson CW, Peskind ER \& Raskind MA 1997 Decreased hypothalamicpituitary-adrenal axis sensitivity to cortisol feedback inhibition in human aging. Neuroendocrinology 65 79-90. (doi:10.1159/ 000127167)

Zhang TY, Ding X \& Daynes RA 2005 The expression of 11ß-hydroxysteroid dehydrogenase type I by lymphocytes provides a novel means for intracrine regulation of glucocorticoid activities. Journal of Immunology 174 879-889.

Received in final form 9 January 2014

Accepted 23 January 2014

Accepted Preprint published online 24 January 2014
(C) 2014 Society for Endocrinology Printed in Great Britain 